\title{
Transient situations in nitrate assimilation by marine diatoms. V. Interspecific variability in biomass and uptake during nitrogen starvation and resupply
}

\author{
Yves Collos* \\ Laboratoíre d'Océanographie URA 41, Campus de Luminy Case 902, F-13288 Marseille Cedex 9, France
}

\begin{abstract}
Nitrate perturbation experiments were carried out on nitrogen-limited and nitrogenstarved marine diatoms under low light intensity to simulate the injection of deep water in the euphotic zone at the level of the thermocline. The potential uptake rate (V'max) of nitrate by Chaetoceros affinis, Thalassiosira pseudonana, and Phaeodactylum tricornutum exhibited significant changes over a time scale of hours during nitrogen starvation. V'max increased during the first $3 \mathrm{~h}$ for $T$. pseudonana, but decreased for $C$. affinis. Upon nitrogen resupply, the direction of change in $V$ 'max was dependent on the species and the duration of incubation. Even though biomass parameters such as chlorophyll indicated a rapid cellular degradation, C. affinis was better adapted to nitrogen deprivation than the other 2 species and was able to exhibit high assimilation numbers and utilize nitrate immediately when starved for less than $48 \mathrm{~h}$.
\end{abstract}

\section{INTRODUCTION}

Marine phytoplankton in stratified oceanic areas can experience sudden increases in nitrate levels through an injection of deep water in the euphotic zone (Walsh et al., 1977; McGowan and Hayward, 1978), sedimentation of cells (Steele and Yentsch, 1960), or vertical migration (Dandonneau, 1977). In a previous paper (Collos, 1980) I examined the adaptation of the nitrate uptake system of a marine diatom to nitrogen starvation and resupply. The present study attempts, through perturbation experiments, to assess the response of 3 species of marine diatoms to an increase in ambient nitrate, simulating the injection of deep water in the euphotic zone, after various periods of nitrogen depletion, representing a range of residence times in the upper layer of a stratified and nutrient-poor water column. Although the nutritional state of phytoplankton with respect to nitrogen in the upper layers of the open ocean is still a matter of debate (McCarthy and

\footnotetext{
- Present address: Centre de Recherche en Ecologie Marine et Aquaculture de l'Houmeau, Case 5, F-17137 Nieul sur mer, France
}

Goldman, 1979; Jackson, 1980; Eppley, 1981), a reasonable assumption is that such phytoplankton is nitrogen depleted and/or starved.

These experiments were designed to supply information on the time scale of changes in uptake parameters to a variation in nutrient regime. Although the need for such data has been recognized for at least 15 yr (Dugdale, 1967), little information actually exists on the problem. This work is part of a program on phytoplankton nutrient dynamics in the region of the thermocline.

\section{METHODS}

Chaetoceros affinis Lauder (isolated from Mediterranean Sea), Thalassiosira pseudonana Hasle and Heimdal clone 13-1 (from Sargasso Sea), and Phaeodactylum tricornutum Bohlin (from Mediterranean Sea) were maintained in batch cultures and grown in nitrogen-limited continuous cultures at a dilution rate of $0.04 \mathrm{~h}^{-1}$ as in Collos and Slawyk (1979), with the following exceptions: The system used here was a cyclostat rather than a chemostat (in the sense of Jannasch, 1974) because of the alternating 

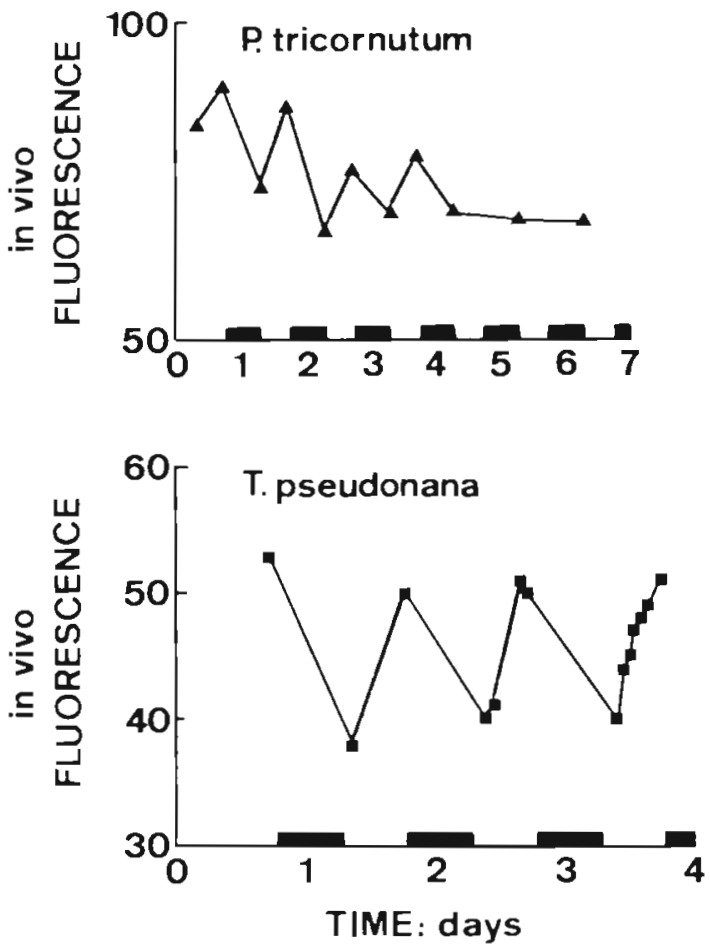

Fig. 1. Changes of in vivo fluorescence (relative units) during approach to steady-state of continuous cultures submitted to a light-dark cycle. Black bars on abscissa: dark period

light and dark regime. It was deemed necessary to use such a system because of important differences in chemical composition as well as metabolic activity observed between cells grown in continuous light and those grown on a light-dark cycle (Caperon and Meyer, 1972; Collos and Lewin, 1976; Laws and Wong, 1978). The term 'cyclostat' is used because it implies diurnal variations in parameters of biomass and kinetics. In practice, however, only changes in cell carbon and in vivo fluorescence (Fig. 1) could be detected between the light and dark phase for biomass parameters.

An Ismatec (Zürich, Switzerland) model IP-4 peristaltic pump was used to supply the medium via Teflon

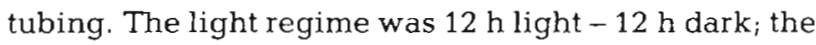
light intensity $\left(125 \mu \mathrm{E} \mathrm{m} \mathrm{m}^{-2} \mathrm{~s}^{-1}\right.$, unless otherwise indicated) corresponded to the irradiance level in the region of the thermocline (about 30 to $40 \mathrm{~m}$ ) located in a stratified oceanic area (Groupe Mediprod, 1977). Temperature was $20^{\circ} \mathrm{C} \pm 1 \mathrm{C}^{\circ}$. Cells were starved for various amounts of time (1 to $72 \mathrm{~h}$ ) while remaining metabolically active. Before starvation experiments, pumping of inflow medium was stopped, and an initial nutrient-response measurement was done $3 \mathrm{~h}$ after the beginning of the light period on a $50 \mathrm{ml}$ sample of the culture. Saturated uptake rates were then determined for various durations of starvation (up to $72 \mathrm{~h}$ ) and incubation ( $5 \mathrm{~min}$ to $1 \mathrm{~h}$ ). These measurements were done either by the chemical method (differences in substrate concentrations over each time interval, as in Collos, 1982), or the isotopic method using the ${ }^{15} \mathrm{~N}$ tracer (Collos and Slawyk, 1979) and in which the equation used for the calculations was the following:

$$
\text { Uptake }=\text { No } \frac{C p-C n a t}{C d-C p}
$$

in units of $\mu \mathrm{g}$ at $\mathrm{N}^{-1}$

where No $_{0}$ particulate nitrogen at time zero; $\mathrm{Cp}=$ concentration of the label (in atom $\%{ }^{15} \mathrm{~N}$ ) in the particulate fraction after incubation; $\mathrm{Cd}=$ concentration of the label (in atom $\%{ }^{15} \mathrm{~N}$ ) in the dissolved fraction at time zero; Cnat $=$ concentration of the label (in atom $\%{ }^{15} \mathrm{~N}$ ) in the particulate fraction at time zero. Nitrate (Wood et al., 1967) and nitrite (Bendschneider and Robinson, 1952) were determined on a Technicon Autoanalyzer with the operating procedures of Tréguer and Le Corre (1975). All incubations were at the same temperature and light intensity as the continuous cultures. Uptake is expressed either in terms of absolute (per cell) or specific (per unit of cell nitrogen) rate (Dugdale, 1977). The symbol V'max is used to indicate that the saturated uptake rate may vary (Dugdale, 1977; McCarthy and Goldman, 1979). Thalassiosira pseudonana was also grown in large volume (6 1) batch cultures to examine the changes in V'max during a period of rapid transition between unlimited growth and nitrogen starvation, and the difference in behavior during starvation between previously limited and unlimited cells.

Particulate carbon and nitrogen were determined as by Collos and Slawyk (1979). In vivo fluorescence was measured with a Turner model 111 fluorometer. Extracted chlorophyll a was estimated as in HolmHansen et al. (1965) on the same instrument.

Growth during starvation is defined as increase in cell numbers or particulate carbon; it was calculated as in Guillard (1973) from cell counts carried out daily on a hemacytometer, or from particulate carbon concentrations.

\section{RESULTS}

\section{Changes in biomass parameters and assimilation numbers during nitrogen starvation and recovery}

Table 1 summarizes growth rates computed from changes in cell numbers and particulate carbon (PC) during the starvation phase of previously nitrogen $(\mathrm{N})$ limited cells. Thalassiosira pseudonana was the most sensitive species and did not grow beyond $24 \mathrm{~h}$ of deprivation. 
Table 1. Growth rates (in $\mathrm{h}^{-1}$ ) computed from cell $(\Delta \mathrm{B})$ and particulate carbon $(\triangle P C)$ increases during a phase of nitrogen starvation

\begin{tabular}{|cccccccc|}
\hline \multirow{2}{*}{$\begin{array}{c}\text { Time } \\
\text { (d) }\end{array}$} & \multicolumn{3}{c}{ Phaeodactylum } & \multicolumn{2}{c}{ Chaetoceros } & \multicolumn{2}{c|}{ Thalassiosira } \\
& $\Delta \mathrm{B}$ & $\Delta \mathrm{PC}$ & $\Delta \mathrm{B}$ & $\Delta \mathrm{PC}$ & \multicolumn{2}{c|}{$\Delta \mathrm{B}$} & $\Delta \mathrm{PC}$ \\
\hline $0-1$ & 0.028 & 0.023 & 0.024 & 0.033 & 0.018 & 0.028 \\
$1-2$ & 0.004 & 0.006 & 0.012 & 0.007 & zero & 0.004 \\
$2-3$ & 0.002 & 0.005 & 0.002 & zero & zero & 0.003 \\
& & & & & & \\
\hline
\end{tabular}

Although cell numbers and PC increased during starvation, chlorophyll a (chla) and assimilation numbers (AN) decreased, but in a quite diverse way (Table 2). While the chla content of the Phaeodactylum tricornutum culture changed only slightly over $3 \mathrm{~d}$, that of the Chaetoceros affinis culture was divided by 2 every day. This allowed this species to exhibit a higher AN than $P$. tricornutum after 24 h of starvation (Day 1 ). As AN were calculated from increases in PC over $24 \mathrm{~h}$ and chla values at the beginning of the light period, these values are lower limits because chla decreased during incubation. Carbon-to-nitrogen composition ratios (PC/PN) are shown to give an idea of the degree of $\mathrm{N}$ deficiency experienced by the cells. Values for Thalassiosira pseudonana were 7.7, 16.9, and 25.2 respectively for 0,24 , and $48 \mathrm{~h}$ of $\mathrm{N}$ starvation respectively. A salient feature of Table 2 is that $C$. affinis exhibited simultaneous high $\mathrm{PC} / \mathrm{PN}$ and high $\mathrm{AN}$ values on Day 1 (24 h of starvation).

Upon addition of nitrate to a 3 d starved culture of this species, the chla content doubled in $5 \mathrm{~h}$ and almost tripled in $7 \mathrm{~h}$, while the in vivo fluorescence (IVF) increased in a much smaller proportion (Table 3 ).

\section{$V^{\prime}$ max as a function of duration of starvation, incubation, and species}

Fig. 2 illustrates the variability in response of different species of diatoms originally limited in $\mathrm{N}$ during a phase of $\mathrm{N}$ starvation. While V'max increased during the first $3 \mathrm{~h}$ for Thalassiosira pseudonana, it decreased for Chaetoceros affinis. Phaeodactylum tricornutum generally exhibited lower uptake values, and a minimum in V'max about $3 \mathrm{~h}$ after the beginning of the starvation period, which corresponded to the middle of the light period.

The units used to express uptake rates could sometimes change the observed patterns in a significant way. For example, in Fig. 2, uptake was expressed on a cell basis, and V'max measured after $24 \mathrm{~h}$ of starvation was significantly different from the initial rate for Chaetoceros affinis, while this was not the case when
Table 2. Evolution of in vivo fluorescence (TVF in relative units), carbon-to-nitrogen composition ratios (PC/PN by atoms), chlorophyll a (chla in $\mu \mathrm{g} \mathrm{l}^{-1}$ ) and assimilation numbers (AN in $\mu \mathrm{gC} \mu \mathrm{g} c h l a^{-1} \mathrm{~h}^{-1}$ ) in cultures of 2 diatoms during nitrogen starvation

\begin{tabular}{|ccccccrrrr|}
\hline $\begin{array}{c}\text { Time } \\
\text { (d) }\end{array}$ & \multicolumn{3}{c}{$\begin{array}{c}\text { Phaeodactylum } \\
\text { tricarnutum }\end{array}$} & & \multicolumn{4}{c|}{$\begin{array}{c}\text { Chaetoceros } \\
\text { affinis }\end{array}$} \\
& IVF & PC/PN & chla & AN & IVF & PC/PN & chla & AN \\
\hline 0 & 64 & 11.6 & 11.4 & 8.9 & 62 & 7.0 & 20.1 & 8.9 \\
1 & 68 & 12.9 & 11.3 & 2.6 & 59 & 17.5 & 10.5 & 5.8 \\
2 & 70 & 15.0 & 11.3 & 0.9 & 50 & 20.7 & 4.7 & 0.5 \\
3 & 38 & 18.5 & 9.8 & - & 50 & 20.4 & 2.6 & - \\
\hline
\end{tabular}

specific uptake rates (in $\mathrm{h}^{-1}$ ) were used (Fig. 3). The differences between initial rates also tended to be smaller when using specific units of uptake (from a 5 fold to a 3 fold difference between $C$. affinis and Thalassiosira pseudonana). In both cases, however, initial rates were related to the $\mathrm{N}$ cell content, which ranged over almost an order of magnitude, with $C$. affinis, T. pseudonana, and Phaeodactylum tricornutum having a $\mathrm{N}$ content of $0.48,0.16$, and $0.06 \mu$ gatN. $10^{6}$ cells $^{-1}$ respectively.

Table 3. Chaetoceros affinis. Evolution of in vivo fluorescence (IVF in relative units) and chla in a culture starved for $3 \mathrm{~d}$ and resupplied with nitrate at a concentration of $10 \mu \mathrm{gat} \mathrm{N} \mathrm{l}^{-1}$

\begin{tabular}{|ccccc|}
\hline $\begin{array}{c}\text { Time } \\
\text { (h) }\end{array}$ & \multicolumn{2}{c}{ IVF } & \multicolumn{2}{c|}{ Chla $\left(\mu \mathrm{g} \mathrm{l}^{-1}\right)$} \\
Control & Expt. & Control & Expt. \\
\hline 0 & 45 & 45 & 7.0 & 7.0 \\
5 & 45 & 63 & 7.0 & 14.0 \\
7 & 45 & 64 & 7.0 & 19.3 \\
\hline
\end{tabular}

It should be noted that these data (Fig. 2 and 3) have been obtained with incubations of $1 \mathrm{~h}$, and that a different picture can emerge from different durations of incubation. In the case of Phaeodactylum tricornutum, for example, V'max remained constant in time under conditions of substrate saturation only for cells starved for less than $24 \mathrm{~h}$, but not beyond (Collos, 1980). Fig. 4 shows time courses of uptake obtained by perturbation experiments carried out on $\mathrm{N}$-starved cultures. Nitrate uptake was followed after addition of $10 \mu$ gat $\mathrm{NO}_{3}-\mathrm{N} \mathrm{I}^{-1}$ until depletion. Here again, there was a great variability of response between species, specially during the first $2 \mathrm{~h}$ of incubation, with $\mathrm{V}^{\prime} \max$ increasing for $P$. tricornutum, decreasing for Chaetoceros affinis, and remaining quite stable for Thalassiosira pseudonana.

A situation of rapid transition with regard to the nitrogenous nutrient regime was studied in a batch culture of the latter species. The increase in specific 


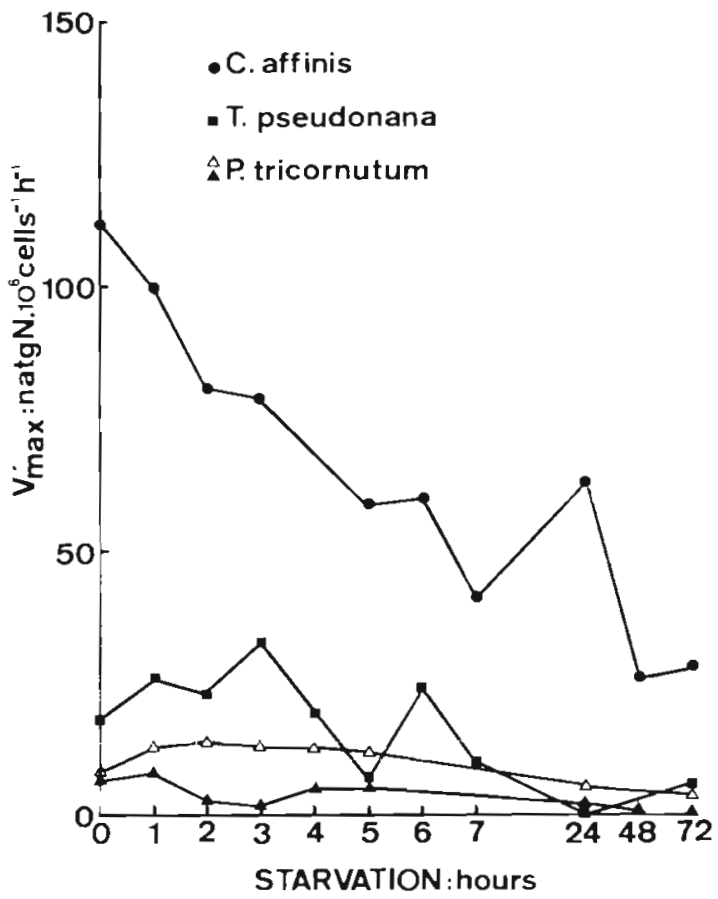

Fig. 2. Changes in saturated nitrate uptake rate (in absolute units) with duration of starvation of previously N-limited cells of 3 diatom species. Open triangles: data from Collos (1980) obtained under continuous light

uptake rate was clear on the first day of deprivation (Table 4), but its magnitude depended on the duration of incubation (from a 4 fold increase with 5 min to a 1.5 fold increase with $60 \mathrm{~min}$ incubations).

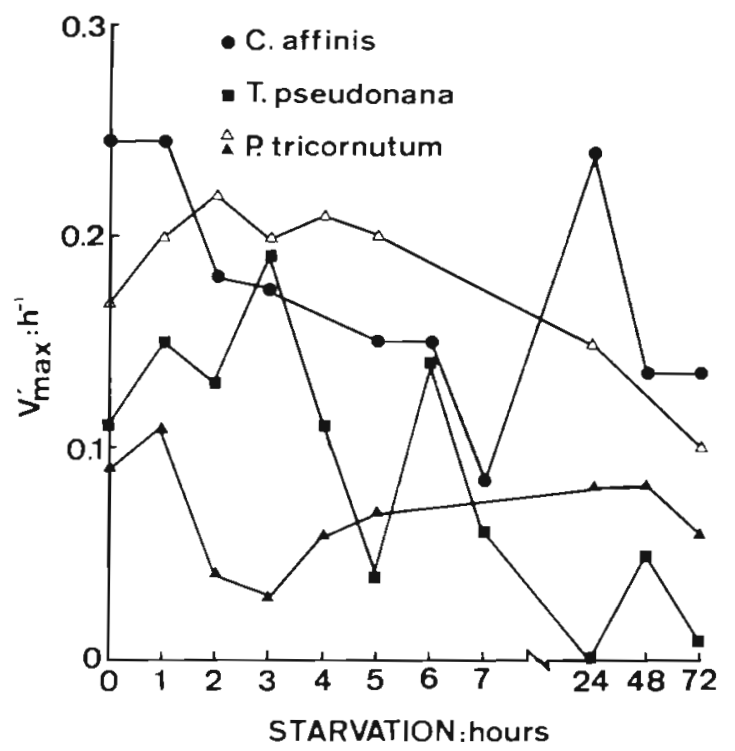

Fig. 3. Changes in saturated nitrate uptake rate (in specific units) with duration of starvation as in Fig. 2

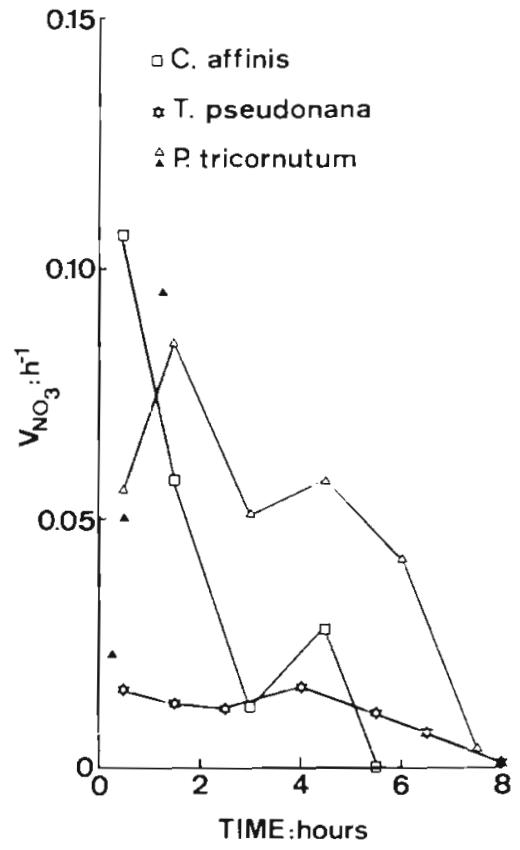

Fig. 4. Changes in nitrate uptake rate with time after a single addition of nitrate to cultures previously starved for $48 \mathrm{~h}$.

Closed triangles are data from Collos (1980)

Table 4. Thalassiosira pseudonana. Saturated nitrate uptake rate $\left(V^{\prime}\right.$ max in $\mathrm{h}^{-1}$ ) during rapid transition between nitrogen unlimited growth and nitrogen starvation. Results obtained with a light intensity of $50 \mu \mathrm{E} \mathrm{m}^{-2} \mathrm{~s}^{-1}$. Nitrate on Day zero was $17 \mu \mathrm{g}$ at $\mathrm{N}^{-1}$ and undetectable on other days. Values for

$\mathrm{V}$ 'max given with a $95 \%$ confidence interval

\begin{tabular}{|ccrc|}
\hline $\begin{array}{c}\text { Time } \\
(\mathrm{d})\end{array}$ & $\begin{array}{c}\mathrm{N} \text { cell content } \\
\left(\mathrm{pg} \text { at } \mathrm{N} \text { cell } \mathrm{I}^{-1}\right)\end{array}$ & $\begin{array}{c}\text { Incubation } \\
\text { duration }\end{array}$ & $\begin{array}{c}\mathrm{V} \text { 'max } \\
\left(\mathrm{h}^{-1}\right)\end{array}$ \\
\hline 0 & 0.20 & $5 \mathrm{~min}$ & $0.038 \pm 0.010$ \\
& & $60 \mathrm{~min}$ & $0.020 \pm 0.004$ \\
1 & 0.15 & $5 \mathrm{~min}$ & $0.137 \pm 0.030$ \\
& 0.12 & $60 \mathrm{~min}$ & $0.029 \pm 0.005$ \\
2 & & $5 \mathrm{~min}$ & $0.016 \pm 0.008$ \\
& & $60 \mathrm{~min}$ & $0.002 \pm 0.002$ \\
\end{tabular}

\section{DISCUSSION}

Concerning changes in biomass parameters and assimilation numbers during starvation, some interesting differences between species are noteworthy. For example, while the chl a of Phaeodactylum tricornutum is practically insensitive to $\mathrm{N}$ starvation, that of Chaetoceros affinis appears to be much more labile. An immediate consequence of this is that high AN can be observed in cells of this species which have been starved for $24 \mathrm{~h}$ and exhibit symptoms of extreme nutrient deficiency such as high PC/PN ratios (Table 2). In this respect, $C$. affinis is similar to $C$. gracilis 
(Thomas and Dodson, 1972), which shows simultaneous high AN (5.8) and high PC/PN ratios (13.9). This is due to the fact that the chla content per cell decreases faster than the carbon uptake rate per cell, a feature also exhibited by Amphiprora paludosa (Glover, 1980).

The chla of natural populations seems to be sensitive to $\mathrm{N}$ deprivation. For example, a 3 fold decrease in chla of a shipboard culture of phytoplankton from the Northwest African upwelling area was observed during a period of nitrate starvation of $7 \mathrm{~h}$ (Collos, 1982). This was paralleled by a 10 fold drop in Vmax for nitrate. The rapid changes in chla during a varying nutrient regime put severe limitations on the use of the $\mathrm{AN}$ as an index of phytoplankton nutritional status. The same can apply for IVF, in view of the lack of sensitivity of this parameter to starvation of Chaetoceros affinis (Table 2).

Concerning uptake patterns, the results presented here with more 'natural' species than in the previous study (Collos, 1980) elucidate the important variability between species which has to be taken into account when dealing with field situations. Especially striking is the contrast between Chaetoceros affinis and Thalassiosira pseudonana, which are exhibiting diametrically opposed trends in V'max during the early starvation phase (Fig. 2 and 3: first 3 h). Note that such an opposition is confirmed at the genus level by the data of Picard (1976) for Chaetoceros and Eppley and Renger (1974) for Thalassiosira. This makes it difficult, for example, to predict the direction of change in Vmax upon injection of deep water into the euphotic zone, and illustrates the importance of adjusting incubations to the time scale of response of the organisms under study.

Another important difference from the previous study is the fact that, under conditions of starvation, an open-ocean species such as Thalassiosira pseudonana cannot reduce its $\mathrm{N}$ content by the same extent as a species typical of eutrophic environments such as Phaeodactylum tricornutum. The 2-fold decrease in $\mathrm{N}$ cell content of the first species (Table 4) is similar to what Maestrini and Kossut (1981) found by exposing the same species to nutrient-poor Mediterranean Sea water for a few days in dialysis bags. In contrast, $P$. tricornutum was able to decrease its $\mathrm{N}$ content by a factor of 4 during $N$ starvation when initially nonlimited by nitrogen (Collos, 1980).

For Thalassiosira pseudonana, the initial V'max (steady-state value) for N-limited cells (Fig. 2) is similar to values published by Caperon and Meyer (1972) and Eppley and Renger (1974) for the same clone at an almost identical dilution rate $(11$ and 17 respectively vs. $18 \mathrm{ng}$ at $\mathrm{N}$. $10^{6}$ cells $\mathrm{s}^{-1} \mathrm{~h}^{-1}$ for the present study). The 2 fold increase in V'max over the first $3 \mathrm{~h}$ of starvation (Fig. 3) is comparable to results obtained on this
(Eppley and Renger, 1974) and another diatom species (Collos, 1980). Unlimited cells of $T$. pseudonana (Table 4) are able to increase their $V^{\prime}$ max in about the same proportions, but over a longer period of deprivation (24 h instead of $3 \mathrm{~h}$ ). The initial uptake rate for those cells is practically equal to the one found by Carpenter and Guillard (1971) for the same clone (8 vs. $6 \mathrm{ng}$ at $\mathrm{N} .10^{6}$ cells ${ }^{-1} \mathrm{~h}^{-1}$ ) growing in batch culture.

These results suggest that V'max goes through a maximum as $\mathrm{N}$ deficiency increases, and then V'max decreases. This pattern was first suggested by Collos and Slawyk (1980) and has now been found experimentally for several species of phytoplankton (Goldman and Glibert, 1982; Terry, 1982). Such a phenomenon may also be the rule for phosphate uptake and associated enzyme activities (Healey, 1978; Burmaster and Chisholm, 1979). Data from Table 4, for example, fit the relation between $V^{\prime} \max$ and $N$ cell content of Thalassiosira pseudonana obtained by Eppley and Renger (1974) and McCarthy and Goldman (1979). Note, however, that their use of several steady-states to characterize this relation does not give an idea of the time scale involved in the observed changes. The present approach does supply such information which appears necessary to model $\mathrm{N}$ uptake correctly in the oceans (Dugdale, 1967).

Dortch et al. (1982) have recently discussed the implications of trends in nitrate uptake during starvation of various species of marine phytoplankton. While the results presented here confirm theirs in the longterm towards a decrease in V'max, some shorter-term trends do show differences. In particular, during the initial starvation period (up to $24 \mathrm{~h}$ ), the increase in V'max of Thalassiosira pseudonana which had been previously grown under $\mathrm{N}$ limitation (Fig. 3) or not (Table 4) may be of importance for short-lived periods of deprivation. Also in contrast to the findings of Dortch et al. (1982) is the observation that Chaetoceros affinis can exhibit an immediate potential for nitrate uptake when starved for less than $48 \mathrm{~h}$. It is not known whether these patterns would be altered if expressed on the basis of cell volume as in the above work. The units of specific uptake rate used here offer the advantage of being directly comparable to ${ }^{15} \mathrm{~N}$ uptake data obtained in field work.

The framework of physical oceanography within which those results must be viewed is cruelly lacking in information about the time scale of nitrate perturbations at sea. While the durations of starvation used in this study compare well with the relaxation periods of a few days which have been observed in upwelling (Coste and Minas, 1982) and coastal (Côté and Platt, 1983) areas, and during which nitrate may be exhausted from surface waters, very little is known on the magnitude and variability of the nitrate flux over 
the long and short term, specially in the region of the thermocline.

Finally, it should be noted that nitrate uptake upon nitrate addition only was studied here, and that interactions with other elements such as phosphate (Terry, 1982) might modify the uptake patterns described in the present study. Data on Phaeodactylum tricornutum, while of limited interest in extrapolations to open ocean conditions, may prove of value in studies of interspecific competition in special habitats such as oyster ponds where this species can be periodically dominant (Maestrini and Robert, 1981).

Acknowledgements. Support for this research came from the Centre National de la Recherche Scientifique (URA 41 and GRECO 130034). I wish to thank Q. Dortch and R. C. Dugdale for stimulating discussions, as well as P. A. Wheeler for comments on an initial draft of the manuscript.

\section{LITERATURE CITED}

Bendschneider, K., Robinson, R. J. (1952). A new spectrophotometric method for the determination of nitrite in sea water. J. mar. Res. 11: 87-96

Burmaster, D. E., Chisholm, S. W. (1979). A comparison of two methods for measuring phosphate uptake by Monochrysis lutheri Droop grown in continuous culture. J. exp. mar. Biol. Ecol. 39: 187-202

Caperon, J., Meyer, J. (1972). Nitrogen-limited growth of marine phytoplankton. II. Uptake kinetics and their role in nutrient-limited growth of phytoplankton. Deep Sea Res. 19: 619-632

Carpenter, E. J., Guillard, R. R. L. (1971). Intraspecific differences in nitrate half-saturation constants for three species of marine phytoplankton. Ecology 52: 183-185

Collos, Y. (1980). Transient situations in nitrate assimilation by marine diatoms. 1. Changes in uptake parameters during nitrogen starvation. Limnol. Oceanogr. 25: 1075-1081

Collos, Y. (1982). Régimes transitoires dans l'assimilation de l'azote par le phytoplancton marin. Thèse Doct. Sci., Univ. Aix-Marseille II

Collos, Y., Lewin, J. C. (1976). Blooms of surf-zone diatoms along the coast of the Olympic Peninsula, Washington. VII. Variations of the carbon-to-nitrogen ratio in field samples and laboratory cultures of Chaetoceros armatum. Limnol. Oceanogr. 21: 219-225

Collos, Y., Slawyk, G. (1979). ${ }^{13} \mathrm{C}$ and ${ }^{15} \mathrm{~N}$ uptake by marine phytoplankton. 1. Influence of the nitrogen source and concentration in laboratory cultures of diatoms. J. Phycol. 15: $186-190$

Collos, Y., Slawyk, G. (1980). Nitrogen uptake and assimilation by marine phytoplankton. In: Falkowski, P. G. (ed.) Primary productivity in the sea. Plenum, New York, p. $195-211$

Coste, B., Minas, H. J. (1982). Analyse des facteurs régissant la distribution des sels nutritifs dans la zone de remontée d'eau des côtes mauritaniennes. Oceanol. Acta 5: 315-324

Côté, B., Platt, T. (1983). Day-to-day variations in the springsummer photosynthetic parameters of coastal marine phytoplankton. Limnol. Oceanogr. 28: 320-344

Dandonneau, Y. (1977). Variations nycthémérales de la pro- fondeur du maximum de chlorophylle dans le dôme d'Angola (Février-Mars 1971). Cah. ORSTOM (sér. Océanogr.) 15: $27-37$

Dortch, Q., Clayton, J. R., Thoresen, S. S., Bressler, S. L. Ahmed, S. I. (1982). Response of marine phytoplankton to nitrogen deficiency: decreased nitrate uptake vs enhanced ammonium uptake. Mar. Biol. 70: 13-19

Dugdale, R. C. (1967). Nutrient limitation in the sea dynamics, identification and significance. Limnol Oceanogr. 12: 685-695

Dugdale, R. C. (1977). Modeling. In: Goldberg, E. D. McCave, I. N., O'Brien, J. J., Steele, J. H. (ed.) The sea, Vol. 6. Wiley, New York, p. 789-806

Eppley, R. W. (1981). Relations between nutrient assimilation and growth in phytoplankton with a brief review of estimates of growth rate in the ocean. In: Platt, T. (ed.) Physiological bases of phytoplankton ecology, Can. Bull. Fish. Aquat. Sci. 210: 251-263

Eppley, R. W., Renger, E. H. (1974). Nitrogen assimilation of an oceanic diatom in nitrogen-limited continuous cultures. J. Phycol. 10: 15-23

Glover, H. E. (1980). Assimilation numbers in cultures of marine phytoplankton. J. Plankton Res. 2: 69-79

Goldman, J. C., Glibert, P. M. (1982). Comparative rapid ammonium uptake by four species of marine phytoplankton. Limnol. Oceanogr. 27:814-827

Groupe Mediprod (1977). Campagne Guidome 1976. Publ. CNEXO, sér. Résult. Campagnes Mer 13: 104

Guillard, R. R. L. (1973). Division rates. In: Stein, J. R. (ed.) Handbook of phycological methods. Culture methods and growth measurements. Cambridge University Press, Cambridge, p. 289-311

Healey, F. P. (1978). Physiological indicators of nutrient deficiency in algae. Mitt. int. Verein. Limnol. 21: 34-41

Holm-Hansen, O., Lorenzen, C. J., Holmes, R. W., Strickland, J. D. H. (1965). Fluorometric determination of chlorophyll J. Cons. perm. int. Explor. Mer 30: 3-15

Jackson, G. A. (1980). Phytoplankton growth and zooplankton grazing in oligotrophic oceans. Nature, Lond. 284 $439-441$

Jannasch, H. W. (1974). Steady-state and the chemostat in ecology. Limnol. Oceanogr. 19: 716-720

Laws, E. A., Wong, D. C. L. (1978). Studies of carbon and nitrogen metabolism by three marine phytoplankton species in nitrate-limited continuous culture. J. Phycol. 14: $406-416$

Maestrini, S. Y., Kossut, M. G. (1981). In situ cell depletion of some marine algae enclosed in dialysis sacks and their use for the determination of nutrient limiting growth in ligurian coastal waters (Mediterranean Sea). J. exp. mar. Biol. Ecol. 50: 1-19

Maestrini, S. Y., Robert, J. M. (1981). Rendements dutilisation des sels nutritifs et variations de l'état des cellules de trois diatomées de claires à huitres de Vendée. Oceanol. Acta $4: 13-21$

McCarthy, J. J., Goldman, J. C. (1979). Nitrogenous nutrition of marine phytoplankton in nutrient-depleted waters. Science, N.Y. 203: 670-672

McGowan, J. A., Hayward, T. L. (1978). Mixing and oceanic productivity. Deep Sea Res. 25: 771-793

Picard, G. (1976). Effects of light and dark cycles on the relationship between nitrate uptake and cell growth rates of Chaetoceros sp. (STX-105) in continuous culture. Ph. D. thesis, City University of New York

Steele, J. H., Yentsch, C. S. (1960). The vertical distribution of chlorophyll. J. mar. biol. Ass, U.K. 39: 217-226

Thomas, W. H., Dodson, A. N. (1972). On nitrogen deficiency 
in tropical pacific oceanic phytoplankton. II. Photosynthetic and cellular characteristics of a chemostat-grown diatom. Limnol. Oceanogr. 17: 515-523

Tréguer, P., Le Corre, P. (1975). Manuel d'analyse des sels nutritifs dans l'eau de mer. Lab. Oceanogr. Chim. Univ. Bretagne Occident

Terry, K. L. (1982). Nitrate uptake and assimilation in Thalassiosira weissflogii and Phaeodactylum tricornutum: interactions with photosynthesis and with the uptake of other ions. Mar. Biol. 69: 21-30

Walsh, J. J., Whitledge, T. E., Kelley, J. C., Huntsman, S. A., Pillsbury, R. D. (1977). Further transition states of the Baja California upwelling ecosystem. Limnol. Oceanogr. 22: $264-280$

Wood, E. J. F., Armstrong, A. J., Richards, F. A. (1967). Determination of nitrate in sea water by cadmium-copper reduction to nitrite. J. mar biol. Ass. U.K. 47: 23-31

This paper was submitted to the editor; it was accepted for printing on January 3,1984 